\title{
Pesticide seed dressings can affect the activity of various soil organisms and reduce decomposition of plant material
}

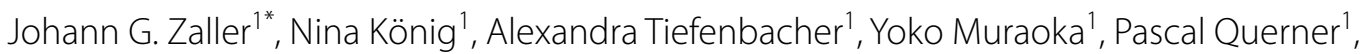 \\ Andreas Ratzenböck², Michael Bonkowski ${ }^{3}$ and Robert Koller ${ }^{3,4}$
}

\begin{abstract}
Background: Seed dressing with pesticides is widely used to protect crop seeds from pest insects and fungal diseases. While there is mounting evidence that especially neonicotinoid seed dressings detrimentally affect insect pollinators, surprisingly little is known on potential side effects on soil biota. We hypothesized that soil organisms would be particularly susceptible to pesticide seed dressings as they get in direct contact with these chemicals. Using microcosms with field soil we investigated, whether seeds treated either with neonicotinoid insecticides or fungicides influence the activity and interaction of earthworms, collembola, protozoa and microorganisms. The full-factorial design consisted of the factor Seed dressing (control vs. insecticide vs. fungicide), Earthworm (no earthworms vs. addition Lumbricus terrestris L.) and collembola (no collembola vs. addition Sinella curviseta Brook). We used commercially available wheat seed material (Triticum aesticum L. cf. Lukullus) at a recommended seeding density of $367 \mathrm{~m}^{-2}$.
\end{abstract}

Results: Seed dressings (particularly fungicides) increased collembola surface activity, increased the number of protozoa and reduced plant decomposition rate but did not affect earthworm activity. Seed dressings had no influence on wheat growth. Earthworms interactively affected the influence of seed dressings on collembola activity, whereas collembola increased earthworm surface activity but reduced soil basal respiration. Earthworms also decreased wheat growth, reduced soil basal respiration and microbial biomass but increased soil water content and electrical conductivity.

Conclusions: The reported non-target effects of seed dressings and their interactions with soil organisms are remarkable because they were observed after a one-time application of only 18 pesticide treated seeds per experimental pot. Because of the increasing use of seed dressing in agriculture and the fundamental role of soil organisms in agroecosystems these ecological interactions should receive more attention.

Keywords: Agricultural intensification, Agroecosystems, Belowground, Difenoconazole, Ecotoxicology, Fludioxonil, Imidacloprid, Pesticides, Prothioconazole, Soil ecology

\section{Background}

Seed dressing in agriculture involves the treatment of various crop seeds with fungicides and/or insecticides in order to combat soil borne fungal diseases and aboveand belowground insects [1]. Neonicotinoid insecticides and fungicides used for seed dressing are increasingly

\footnotetext{
*Correspondence: johann.zaller@boku.ac.at

${ }^{1}$ Institute of Zoology, University of Natural Resources and Life Sciences Vienna (BOKU), Vienna, Austria

Full list of author information is available at the end of the article
}

applied for many agricultural crops for about 15 years [2, $3]$. Recently, especially systemic neonicotinoid pesticides used for seed dressing have been shown to affect the fitness and mortality of a variety of non-target invertebrates $[4,5]$. Especially their connection to increased bee mortality resulted in a moratorium on three neonicotinoids as seed dressing within the European Union [6]. While our knowledge on non-target effects of pesticide seed dressings on insect pollinators is mounting $[5,7]$, we still know very little on potential impacts on soil biota. This 
is surprising since the bulk of the active ingredients from seed dressings have been shown to enter the soil and thus directly impacting soil biota [2].

Of the highly diverse soil biota, earthworms are vitally important members especially in agricultural soils where they can constitute up to $80 \%$ of total soil animal biomass [8]. They play critical roles in the development and maintenance of soil physical, chemical and biological properties [9]. Their activities improve soil structure by increasing porosity and aeration, facilitating the formation of aggregates and reducing compaction $[10,11]$. Soil fertility is enhanced by earthworm casting activities [12] and the modification of microbial biomass and activity [13]. Collembola (springtails) are another very important part of soil fauna by driving plant litter decomposition processes $[14,15]$. Other key components of the soil food web are heterotrophic protists (hereafter 'protozoa') that are involved in soil fertility and plant productivity as they remobilize nutrients formally locked in bacterial biomass $[16,17]$ and link energy fluxes towards higher trophic levels $[18,19]$.

Pesticides have been shown to affect earthworms from the physiological to community level, where insecticides and fungicides appear to be the most toxic pesticides [20, 21]. Recently, also broad-band herbicides have been demonstrated to impact earthworms and mycorrhizal fungi $[22,23]$. In an extensive review on non-target effects of neonicotinoids several deleterious effects on soil organisms have been shown [24]. Neonicotinoids in seed dressings have been reported to decrease earthworm activity, burrowing and growth [25-28] and also affect terrestrial isopods [29] and soil microorganisms [30]. When a neonicotinoid was used as a lawn treatment to target neonate white grubs (Coleoptera: Scarabaeidae) an averaged $58 \%$ reduction of non-target abundance of Hexapods, collembola, Thysanoptera and Coleoptera was seen [31, 32]. Several other studies also showed detrimental effects of neonicotinoids on collembola [33, 34]. Substantially less is known on potential side effects of fungicide seed dressings. However, as both earthworms and collembola feed on fungi living in the soil $[35,36]$ few studies indeed found that both collembola [37] and earthworms [38] can be affected by fungicide seed dressings. However, to our knowledge no study tested direct or indirect feedbacks on the impact of insecticide and/or fungicide seed dressings on Protozoa.

The aim of the present study was (i) to test the impact of insecticide and/or fungicide seed dressings on the activity or abundance of various soil biota ranging from microorganisms to macrofauna, (ii) to examine whether potential effects of seed dressings might be altered by the activity of soil meso and/or macrofauna (i.e. collembola or earthworms) and (iii) to quantify feedbacks of seed dressings on the functional capacity of soil biota to decompose plant litter. Because of their direct incorporation into the soil we hypothesized that pesticides in seed dressings will directly affect soil organisms of different functional and phylogenetic affiliations. Neonicotinoid insecticides will affect collembola because of their close phylogenetic relationship to insects and fungicides will indirectly affect earthworms and collembola as they both feed on soil fungi or by direct side effects. Including species interactions in potential non-target pesticide effects should provide a more realistic evaluation of the situation in agroecosystems $[21-23,39]$.

\section{Methods \\ Study system}

This experiment was conducted between 21 October and 16 December 2013 (58 days) in a greenhouse of the University of Natural Resources and Life Sciences (BOKU), Vienna, Austria. Experimental units, further called microcosms, consisted of polypropylene tubes (diameter $25 \mathrm{~cm}$, height $60 \mathrm{~cm}$ ) commonly used for sanitary tubing (type "PP-MEGA-Rohr 8"; Bauernfeind, Waizenkirchen, Austria). The bottoms of the tubes were closed with mosquito net and placed on saucers. Barriers of transparent plastic foil $(20 \mathrm{~cm}$ high) were glued on the upper rim of each pot in order to prevent earthworms from escaping; these barriers were additionally smeared with soft soap on the upper edges.

Each microcosm was filled with 28.51 of a substrate mixture made of $75 \%(\mathrm{vol} / \mathrm{vol})$ arable field soil and $25 \%$ of commercial potting soil containing bark humus, wood fibres, compost of green waste, sand and mineral fertilizer ("green Pflanzerde"; BauMax, Klosterneuburg, Austria). Field soil was obtained from an arable field of the research farm of the University of Natural Resources and Life Sciences located in the village of Groß-Enzersdorf near Vienna, Austria. The two substrate types were thoroughly mixed using a concrete mixer. Characteristics of the substrate mixture: $\mathrm{N}_{\text {tot }}=0.143 \pm 0.05 \mathrm{~g} \mathrm{~kg}^{-1}$, $\mathrm{P}=147.3 \pm 13.8 \mathrm{mg} \mathrm{kg}^{-1}, \mathrm{~K}=289.5 \pm 22.1 \mathrm{mg} \mathrm{kg}^{-1}$, $\mathrm{C}: \mathrm{N}$ ratio 20.15, $\mathrm{pH}=7.45 \pm 0.02$. Microcosms were randomly arranged on the floor of the greenhouse.

\section{Experimental factors}

A full-factorial design with three factors was assigned to totally 60 microcosms; each factor combination was replicated five times.

Factor Seed dressing consisted of three levels of treated winter wheat seeds (Triticum aestivum L. var. Lukullus): No seed dressing, seed dressing with insecticides and fungicides (further called "insecticide seed dressing" because of the dominating insecticidal ingredients), seed dressing with fungicides only (further called "fungicide 
seed dressing"). Insecticide seed dressing consisted of the insecticide Gaucho ${ }^{\circledR} 600 \mathrm{FS}+\mathrm{Redigo}^{\circledR}(600 \mathrm{~g} / \mathrm{l}$ imidacloprid $+100 \mathrm{~g} / \mathrm{l}$ prothioconazole; Bayer CropScience; Monheim, Germany) combined with the fungicide CELEST ${ }^{\circledR}$ Extra 050 FS (25 g/l difenoconazol, 25 g/l fludioxonil; Syngenta Agro, Vienna, Austria). Fungicide seed dressing consisted of EfA ${ }^{\circledR}$ UNIVERSAL (75 g/l fluoxastrobin, $10 \mathrm{~g} / \mathrm{l}$ fluopyram, $7.5 \mathrm{~g} / \mathrm{l}$ tebuconazole, $50 \mathrm{~g} / \mathrm{l}$ prothioconazole; Bayer CropScience; Monheim, Germany). Control seeds had no dressing with pesticides. The seed material we used for this experiment was provided by the Austrian Agency for Health and Food Safety (AGES, Vienna, Austria) and is in this quality also available for farmers in Austria. We sowed 18 seeds per pot in $3 \mathrm{~cm}$ depth resulting in a density of 367 seeds $\mathrm{m}^{-2}$ which is within the recommended seeding density of $220-450$ seeds $\mathrm{m}^{-2}$ for this variety (www.agrarvis.de/pflanzen). Variety Lukullus is regarded as quality wheat in Austria with excellent baking quality, high protein content particularly suitable for dry sites [40]. At the beginning, all microcosms were watered twice with $1.5 \mathrm{l}$ of tap water to ensure maceration of seeds; afterwards all pots were regularly irrigated with the same amount of tap water depending on the temperature conditions in the greenhouse.

Factor earthworm consisted of two levels: addition of four adult individuals per microcosm $(14.7 \pm 2.1 \mathrm{~g}$ fresh mass) of the vertically burrowing species Lumbricus terrestris L. (+EW) or no earthworm addition (-EW). Adult specimens of $L$. terrestris were purchased from a bait shop (Anglertreff, Vienna, Austria) and acclimatized in field soil for 6 days in the climate chamber $\left(15{ }^{\circ} \mathrm{C}\right)$ under complete darkness. Before introducing them to the microcosms, the earthworms were rinsed with tap water, dried with a hand towel and weighed. All earthworms buried themselves within a few minutes. One earthworm was lying dead on the soil surface 2 days after insertion and was immediately substituted by another one.

Factor collembola consisted of two levels and was established either by adding 100 Collembola of the species Sinella curviseta Brook, 1882 (Entomobryidae; treatment $+C$ ) to half of the microcosms immediately after seeding (21 October 2013) or by adding no collembola (treatment -C). Collembola were obtained from a commercial supplier (Megazoo, Vienna, Austria). To provide abundant food for earthworms and Collembola, $3.5 \mathrm{~g}$ microcosm $^{-1}$ of chopped hay and $0.2 \mathrm{~g} \mathrm{microcosm}^{-1}$ fish fodder (TetraMin ${ }^{\circledR}$ ) was spread on the soil surface of each experimental unit over the cource of the experiment in order to keep the nutrient input similar between treatments.

The earthworm species used is native to Central European agroecosystems [41], the collembola species used is native to Europe, Southeast Asia (especially China) and north-western parts of the USA [37].

\section{Measurements \\ Earthworms}

The activity of earthworms was assessed using the toothpick method [22]. Briefly, regular wooden toothpicks are vertically inserted into the soil (ca. $3 \mathrm{~mm}$ deep) before sunset, the next morning the inclined or fallen toothpicks were assessed. Vertically burrowing earthworms will come to the soil surface during night in order to forage for food and will thereby knock over toothpicks. We used 12 toothpicks per microcosm and conducted this assessment twice a week. Another method we used to assess earthworm activity was the counting of earthworm casts deposited on the soil surface. All surface casts were counted and collected twice a week. The casts were dried at $40^{\circ} \mathrm{C}$ for $48 \mathrm{~h}$ and weighed.

\section{Collembola}

The activity of Collembola was determined using pitfalltraps [42]. Therefore, five uncovered $2 \mu \mathrm{l}$ Eppendorf tubes (diameter $9.85 \mathrm{~mm}$ ) were carefully inserted so deep that the upper rim of the tubes was at the level of the soil surface. Tubes were inserted around the centre of each microcosm using a consistent pattern among microcosms. Pitfall-traps were filled with conservation fluid consisting of $95 \%$ ethylene glycol and a drop of odourless detergent. Sampling started 4 days after the addition of collembola on 25 October; after 4 days of exposure the pitfall-traps were replaced with new ones, which were exposed for another 4 days. Four sampling intervals each with a four-day exposure were made. Between 14 November and 16 December 2013 five samplings with six-day exposure interval were made. All specimens captured in the pitfall traps were stored in $95 \%$ ethylene glycol at room temperature until they could be counted and assigned taxonomically.

In addition to the test organism two other Collembola species were found: two individuals of Sminthurinus domestica and one individual of Entomobrya multifasciata. Because these latter two species were so rare, they were excluded from further calculations. Daily Collembola activity was calculated by dividing the cumulated number of trapped Collembola by the number of days of pitfall trap exposure.

\section{Soil moisture, electrical conductivity and temperature}

These soil parameters were measured twice a week when assessing earthworm activity using time domain reflectrometry (TRIME ${ }^{\circledR}$-PICO 64/32, Micromodultechnik GMBH, Ettlingen, Germany). 


\section{Wheat growth}

Growth of winter wheat was assessed weekly on all 18 plants per microcosm by measuring the maximum leaf length from the soil surface using a ruler. Aboveground winter wheat biomass was destructively harvested on 16 December (58 days after seeding) by cutting all wheat plants at the soil surface. Wheat biomass was assessed after drying the plant material at $55^{\circ} \mathrm{C}$ for $48 \mathrm{~h}$.

\section{Litter decomposition in soil}

Litter decomposition in soil was determined using the Tea Bag Index [43]. Therefore, one commercially available pyramid shaped plastic tea bag of green tea (EAN: 8722700055525 ) and one tea bag of rooibos tea (EAN: 8722700188438 ) were buried at a depth of $8 \mathrm{~cm}$ in each microcosm (Lipton Tea, Washington St, USA). The mesh size of the tea bags of $0.25 \mathrm{~mm}$ allows microorganisms to enter, but meso and macrofauna are excluded [44]. Before the insertion into the microcosms individual tea bags were weighed, tea bags remained in the microcosms for 58 days. After the removal from the microcosms, the tea bags were cleaned from sticking soil particles and dried at $70{ }^{\circ} \mathrm{C}$ for $48 \mathrm{~h}$. The bags were opened and the content was weighed. The calculation scheme determined the decomposition rate $(\mathrm{k})$ and the stabilisation factor $(\mathrm{S})$ considering the hydrolysable fraction $0.842 \mathrm{~g} \mathrm{~g}^{-1}$ for green tea and $0.552 \mathrm{~g} \mathrm{~g}^{-1}$ for rooibos tea [43]. Green tea and rooibos tea have different decomposition rates meaning that rooibos tea decomposes slower and still continues, when labile material in green tea has already been consumed. The stabilisation process begins during the decomposition of the labile fraction of organic material [45]. This method was also used to assess non-target effects of herbicides [23].

\section{Soil microorganisms}

Soil microbial biomass $\left(\mathrm{C}_{\text {mic }}\right)$ was determined from a $3 \mathrm{~g}$ subsample of $20 \mathrm{~g}$ of fresh surface soil $(0-3 \mathrm{~cm})$ taken on three random locations per microcosm 54 days after seeding (12 December 2013). Soil was stored in polypropylene plastic bags, cooled and expressed-mailed to the University of Cologne, Germany, where the analyses on soil microbes were conducted. Microbial biomass was measured by substrate-induced respiration [46] using an automated respirometer based on electrolytic $\mathrm{O}_{2}$ micro compensation [47], as outlined in [48]. For basal respiration, the average $\mathrm{O}_{2}$ consumption rate of samples not amended with glucose was measured during 15-20 h after attachment of samples to the respirometer. Microbial specific respiration $\left(\mathrm{qO}_{2}, \mu \mathrm{O}_{2} \mu \mathrm{g}^{-1} \mathrm{C}_{\text {mic }} \mathrm{h}^{-1}\right)$ was calculated as the quotient between basal respiration and microbial biomass.

For the quantification of Protozoa (Amoebae and Flagellates), soil samples were taken from the top $3 \mathrm{~cm}$ from three random locations per microcosm 54 days after seeding (12 December 2013). The soil was homogenized and stored at $5{ }^{\circ} \mathrm{C}$ until usage. Amoebae and Flagellates were counted using a modified most probable number method [49]. Briefly, $5 \mathrm{~g}$ fresh weight of soil was suspended in $20 \mathrm{ml}$ sterile Neff's modified amoebae saline (NMAS; [50]) and gently shaken for $20 \mathrm{~min}$ on a vertical shaker. Threefold dilution series with nutrient broth (Merck, Darmstadt, Germany) and NMAS at 1:9 v/v were prepared in 96-well microtiter plates (VWR, Darmstadt, Germany) with four replicates, each. The microtiter plates were incubated at $15^{\circ} \mathrm{C}$ in darkness and the wells were inspected for presence of protozoa using an inverted microscope at $100 \times$ and $200 \times$ magnification (Nikon, Eclipse TE 2000-E, Tokyo, Japan) after 3, 6, 11, 19 and 26 days. Densities of protozoa were calculated according to [51].

\section{Air temperature and relative humidity}

Air temperature and relative humidity in the greenhouse was monitored using Tinytag dataloggers (Tinytag Plus 2, Gemini Data Loggers Ltd, Chichester, West Sussex, UK). Mean daily air temperature during the course of the experiment was $17.9{ }^{\circ} \mathrm{C}$ and at a mean relative humidity of $64.4 \%$.

\section{Statistical analyses}

All statistical tests were carried out using R-software vers. R-3.0.2 for Windows (www.r-project.org). All data were tested for normal distribution by the ShapiroWilk test and homogeneity of variance by the Levene test. Three factorial analysis of variance (ANOVA) with the factors seed dressing, earthworms, collembola and their interactions was used to examine effects on wheat growth, wheat biomass, soil microbial parameters, litter decomposition, soil abiotic parameters. Two factorial ANOVAs with the factors seed dressing and collembola were used to test effects on total cumulated earthworm surface activity. Two factorial ANOVAs with the factors Seed dressing and Earthworms were used to test effects on total cumulated collembola surface activity. Posthoc Tukey comparisons were used to test effects of treatment factors at individual treatments. Differences were considered significant when $\mathrm{P}<0.05$ and marginally significant when $0.07<\mathrm{P}>0.05$. All values given in the text are means with the appropriate standard deviation $($ mean $\pm \mathrm{SD})$.

\section{Results}

Generally, we observed earthworm and collembolan activity throughout the course of the experiment. Seed dressing significantly increased the cumulated surface activity of collembola (Fig. 1; Table 1), decreased 

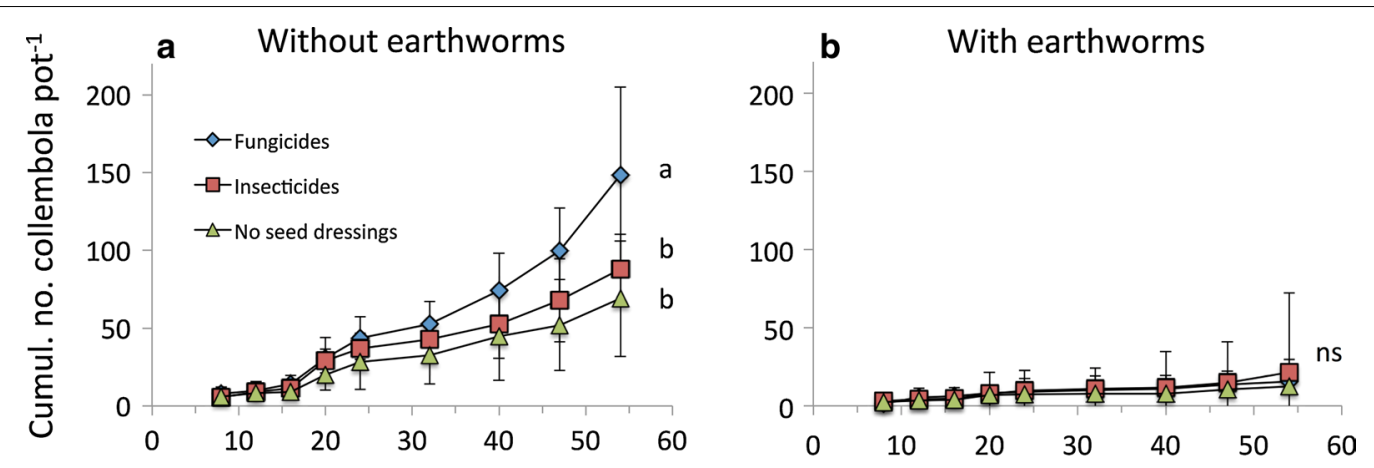

Days after seeding

Fig. 1 Collembola activity in response to pesticide seed dressings in microcosms without (a) and with earthworms (b). Mean $\pm S D, n=5$. Different letters denote significant differences between seed dressings, ns no significant difference

litter decomposition rates and marginally significantly increased the abundance of soil protozoa (Fig. 2; Table 1). Fungicide seed dressings increased cumulative collembola activity when earthworms were absent (Fig. 1a). Cumulative collembola activity was highest after fungicide seed dressing (148 \pm 14 ind. pot $\left.^{-1}\right)$, followed by insecticide seed dressing (88 \pm 5 ind. pot $^{-1}$;) and no seed dressing (69 \pm 5 ind. pot $^{-1}$, Fig. 1a). Collembola surface activity was unaffected by seed dressings when earthworms were present (i.e. significant seed dressing $\times$ earthworm interaction; Fig. 1b; Table 1). Daily collembola activity was significantly increased by fungicide seed dressings (averaged $4.12 \pm 0.70$ ind. pot $^{-1}$ day $^{-1}$ ) while insecticide seed dressing and non-treated seeds showed similar activities $\left(2.44 \pm 0.27\right.$ ind. pot $^{-1}$ day $^{-1}$ and $1.92 \pm 0.46$ ind. pot $^{-1}$ day $^{-1}$, respectively; data not shown). Litter decomposition rate was significantly reduced by both fungicide and insecticide seed dressings (on average $0.029 \pm 0.006$ ) and higher when no seed dressings were used ( $0.050 \pm 0.026$; Fig. 2 c; Table 1$)$. Both types of seed dressings marginally significantly increased protozoa densities (Fig. 2d; Table 1). All other soil or plant parameters measured remained unaffected by seed dressings (Table 1).

Earthworms significantly reduced the surface activity of cumulative collembola activity (Fig. 1; Table 1), reduced soil basal respiration regardless of seed dressing (Fig. 2a) and reduced microbial biomass only when seed dressing was used (Fig. 2b). Additionally, earthworms increased soil water content and soil electrical conductivity (Tables 1, 2). Collembola significantly increased earthworm surface casting activity (Fig. 3; Table 1) and increased soil basal respiration (Fig. 2a; Table 1). Interactions between seed dressing and earthworms or between earthworm and collembola affected soil $\mathrm{qCO}_{2}$ (Table 1$)$.
The average germination rate of wheat seeds among treatments was $91.9 \pm 9.3 \%$, however this was not affected by any treatment factor (Table 1). Wheat growth was significantly and wheat biomass marginally significantly reduced by earthworms, however wheat growth was not affected by seed dressing or collembola (Fig. 4; Table 1). The mean final height of wheat was $33.8 \pm 2.3 \mathrm{~cm}$ at $0.83 \pm 0.30 \mathrm{~g}$ biomass when $L$. terrestris was present and $43.2 \pm 3.5 \mathrm{~cm}$ at $0.69 \pm 0.14 \mathrm{~g}$ without $L$. terrestris (Fig. 4).

\section{Discussion}

This is among the first studies investigating realistic dosages of pesticide seed dressings on the activity of a variety of soil organisms and their consequence for ecosystem functioning exemplified by plant litter decomposition and crop growth. We found that fungicide seed dressings increased the activity of collembola and both insecticide and fungicides seed dressings increased the abundance of flagellate protozoa but decreased litter decomposition. Earthworm activity was not affected by seed dressings, however earthworms altered the response of collembola and soil microorganisms to seed dressings (i.e. seed dressing $\mathrm{x}$ earthworm interactive effects).

Soil fauna actively contributes to litter breakdown by grinding plant residues and thus increasing the surface area where bacteria and fungi actively mineralize carbon and nutrients $[52,53]$. In our experiment litter decomposition rate was reduced by seed dressings, regardless whether insecticides or fungicides were used. As fungicides were also combined with the neonicotinoid insecticide seed dressings in the commercial seed material we used in the current experiment this indicates that neonicotinoids present in seed dressings had no additional effect on litter decomposition. The mesh size of 
Table 1 ANOVA-results on the effects of seed dressings, earthworms and collembola on soil and plant parameter

\begin{tabular}{|c|c|c|c|c|c|c|c|c|c|c|c|c|}
\hline \multirow[t]{2}{*}{ Parameter } & \multicolumn{2}{|c|}{$\begin{array}{l}\text { Seed dress- } \\
\text { ing (SD) }\end{array}$} & \multicolumn{2}{|c|}{$\begin{array}{l}\text { Earthworms } \\
\text { (EW) }\end{array}$} & \multicolumn{2}{|c|}{$\begin{array}{l}\text { Collembola } \\
\text { (coll) }\end{array}$} & \multicolumn{2}{|c|}{$S D \times E W$} & \multicolumn{2}{|c|}{ SD $\times$ coll } & \multicolumn{2}{|c|}{$\mathrm{EW} \times$ coll } \\
\hline & $F$ & $\mathbf{P}$ & $\mathrm{F}$ & $\mathbf{P}$ & $\mathrm{F}$ & $\mathbf{P}$ & $\mathrm{F}$ & $\mathbf{P}$ & $F$ & $\mathbf{P}$ & $\mathbf{F}$ & $\mathbf{P}$ \\
\hline \multicolumn{13}{|l|}{ Earthworms } \\
\hline Surface activity (toothpicks) & 2.37 & 0.104 & - & - & 2.97 & 0.091 & - & - & 1.42 & 0.253 & - & - \\
\hline Surface activity (no. casts) & 0.78 & 0.464 & - & - & 8.02 & 0.007 & - & - & 0.30 & 0.739 & - & - \\
\hline Surface activity (cast mass) & 0.75 & 0.479 & - & - & 2.87 & 0.097 & - & - & 0.91 & 0.411 & - & - \\
\hline \multicolumn{13}{|l|}{ Collembola } \\
\hline Surface activity (total no.) & 5.04 & 0.010 & 62.56 & $<0.001$ & - & - & 4.97 & 0.011 & - & - & - & - \\
\hline Surface activity (daily no.) & 1.41 & 0.250 & 9.87 & 0.003 & - & - & 1.90 & 0.159 & - & - & - & - \\
\hline \multicolumn{13}{|l|}{ Protista } \\
\hline Flagellates (abundance $\mathrm{g}^{-1}$ soil) & 3.36 & 0.053 & 0.13 & 0.720 & - & - & 0.16 & 0.849 & - & - & - & - \\
\hline Amoebae (abundance $\mathrm{g}^{-1}$ soil) & 1.54 & 0.237 & 0.03 & 0.855 & - & - & 0.17 & 0.842 & - & - & - & - \\
\hline Protozoa (abundance $\mathrm{g}^{-1}$ soil) & 3.31 & 0.055 & 0.01 & 0.933 & - & - & 0.02 & 0.979 & - & - & - & - \\
\hline \multicolumn{13}{|l|}{ Soil microorganisms } \\
\hline Basal respiration $\left(\mu \mathrm{g} \mathrm{CO}_{2}-\mathrm{Cg}^{-1} \mathrm{~h}^{-1}\right)$ & 1.01 & 0.372 & 14.794 & $<0.001$ & 4.56 & 0.038 & 0.47 & 0.628 & 0.78 & 0.492 & 0.03 & 0.866 \\
\hline Microbial biomass $C_{\text {mic }}\left(\mu \mathrm{g} \mathrm{Cg}{ }^{-1}\right)$ & 0.26 & 0.773 & 4.07 & 0.049 & 0.02 & 0.881 & 0.48 & 0.619 & 0.54 & 0.585 & 1.93 & 0.171 \\
\hline Metabolic quotient $\mathrm{qCO}_{2}\left(\mu \mathrm{g} \mathrm{CO}{ }_{2}-\mathrm{Cg}^{-1} \mathrm{~h}^{-1} \mathrm{C}_{\text {mic }} \mathrm{h}^{-1}\right)$ & 0.98 & 0.382 & 0.03 & 0.856 & 1.51 & 0.225 & 2.91 & 0.064 & 0.73 & 0.489 & 7.99 & 0.007 \\
\hline \multicolumn{13}{|l|}{ Litter decomposition } \\
\hline Decomposition rate $(\mathrm{k})$ & 3.80 & 0.043 & 0.01 & 0.955 & 0.45 & 0.507 & 0.19 & 0.825 & 1.03 & 0.368 & 1.01 & 0.322 \\
\hline Stabilisation factor (S) & 0.25 & 0.779 & 0.29 & 0.588 & 1.34 & 0.254 & 0.26 & 0.769 & 2.07 & 0.139 & 1.80 & 0.187 \\
\hline \multicolumn{13}{|l|}{ Soil abiotic parameters } \\
\hline Water content (\%) & 1.98 & 0.149 & 20.83 & $<0.001$ & 1.52 & 0.224 & 0.90 & 0.412 & 0.53 & 0.589 & 0.01 & 0.983 \\
\hline Temperature $\left({ }^{\circ} \mathrm{C}\right)$ & 0.05 & 0.951 & 2.71 & 0.106 & 0.17 & 0.678 & 0.83 & 0.443 & 0.15 & 0.864 & 0.66 & 0.422 \\
\hline Electrical conductivity $\left(\mathrm{mS} \mathrm{m}^{-1}\right)$ & 0.02 & 0.980 & 9.30 & 0.004 & 0.01 & 0.958 & 2.22 & 0.119 & 0.09 & 0.915 & 0.01 & 0.957 \\
\hline \multicolumn{13}{|l|}{ Wheat parameter } \\
\hline Germination rate (\%) & 0.51 & 0.601 & 0.01 & 0.998 & 0.51 & 0.477 & 1.25 & 0.295 & 0.51 & 0.601 & 0.03 & 0.859 \\
\hline Height (cm) & 2.11 & 0.133 & 93.77 & $<0.001$ & 0.06 & 0.799 & 0.47 & 0.627 & 0.06 & 0.945 & 0.85 & 0.362 \\
\hline Biomass (g) & 0.87 & 0.424 & 3.84 & 0.056 & 0.14 & 0.705 & 0.21 & 0.815 & 0.69 & 0.506 & 0.53 & 0.472 \\
\hline
\end{tabular}

No data available

Significant effects in italics; model degrees of freedom: seed dressing $\mathrm{df}=2$, earthworms $\mathrm{df}=1$, collembola $\mathrm{df}=1$

the teabags we used $(0.25 \mathrm{~mm})$ also prevented the direct contribution of meso and macrofauna to litter breakdown [44], making the insecticide perhaps less relevant. Overall soil microbial biomass and activity was not affected by seed dressings suggesting potential shifts in soil fungal community composition rather than overall decrease in microbial (fungal) biomass and an increased nutrient input by decomposing fungi [54]. Our finding of reduced litter decomposition rates due to seed dressings could also be explained by increased protozoa abundance as protozoan grazing has been shown to affect the bacterial community structure in soil microcosms [55]. This assumption is further underpinned by strong increase in abundance of flagellate protists. Although flagellates may quickly respond to environmental changes $[56,57]$ the strong increase in the abundance of flagellate protist is surprising and reveals an important impact of seed dressings on basic soil food web functioning. Especially mycophageous flaggelates may have increased resource availability or reduced competition for resources that led to a twofold increase of flagellate cells. To the best of our knowledge, the present study is among the first ones reporting effects of pesticide seed dressings on protozoa. With abundances of several 100,000 individuals $\mathrm{g}^{-1}$ soil protozoa are at the base of the heterotrophic eukaryotic food web and an essential component in soil ecosystems because they consume a significant portion of the bacterial productivity, enhancing nutrient cycles and energy flows to the benefit of microorganisms, plants and animals [58-61]. Protozoa are also important grazers of rhizobacteria and can even influence aboveground herbivores [62].

In contrast to our hypothesis that collembola are strongly sensitive to insecticide seed dressing due to their close phylogenetic relationship to insects, seed dressings that only contained fungicides more strongly impacted 

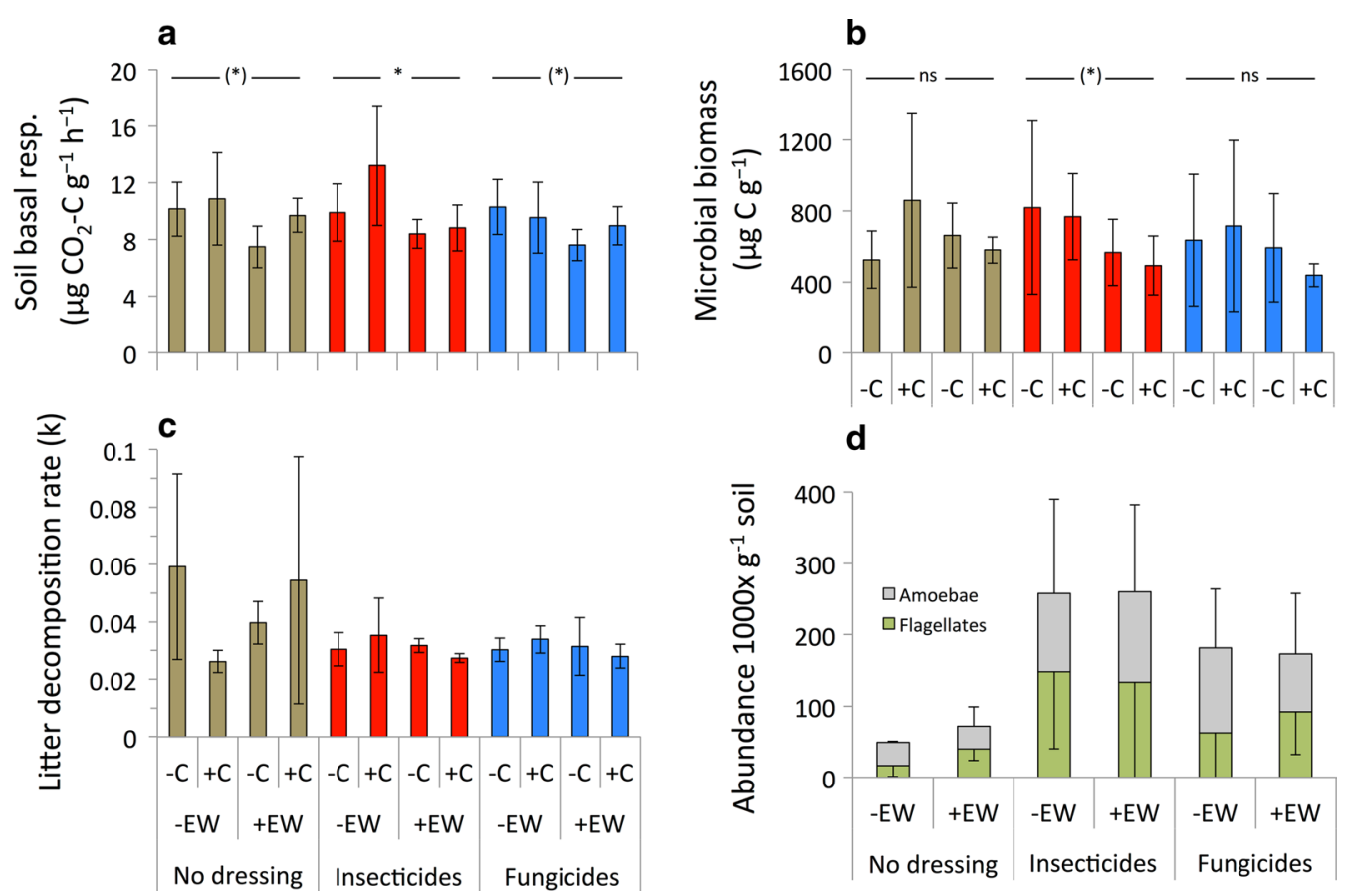

d

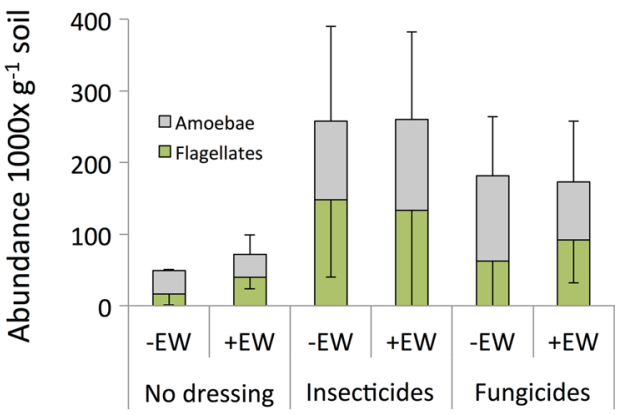

Fig. 2 Soil basal respiration $(\mathbf{a})$, microbial biomass $(\mathbf{b})$, soil decomposition rate $(\mathbf{c})$ and protozoa abundance $(\mathbf{d})$ in response to pesticide seed dressings in microcosms without $(-C)$ or with collembola $(+C)$, without $(-E W)$ or with earthworms (+EW). Mean $\pm S D, n=5$. Horizontal lines indicate mean comparisons between earthworm treatments when interactions were significant: * denotes significant difference, $\left({ }^{*}\right)$ marginally significant difference, $n s$ no significant difference

collembola with an $250 \%$ increase in surface activity and a $40 \%$ increase in their reproduction rate. A higher surface activity of collembola might also be the consequence of an avoidance of soil areas contaminated with insecticide treated seeds. To what extent this can be interpreted as a reaction to chemical stressors needs to be investigated in specific behavioural experiments. Indeed, others also found an increased surface activity of collembola after application of seeds dressed with the neonicotinoid insecticide imidacloprid in the field [63]. Similary to flagellates, fungizide seed dressings may have increased resource availability for collembola, e.g. by increasing abundance of fast growing fungi that contain less toxins [64]. When fungicides and insecticides were sprayed, collembola were especially vulnerable [65] and have long been used as indicator species to asses non-target effects of agrochemicals [66].

Although, micro and mesofauna was affected by seed dressings, we found no clear effect on the casting activity of earthworms. This is a remarkable finding as earthworms are also known to feed on plant seeds [67-69]. In contrast, lethal and sublethal effects of neonicotinoid insecticides on earthworms have been documented by several studies [20, 26, 27]. However, these studies either considered sprayed insecticides and/or only tested the active ingredients while in the current study the complete formulations used by farmers, i.e. active ingredients including all (often non-declared adjuvants), were tested.

Earthworms altered effects of seed dressing on collembolan surface activity. We assume that the physical disruption by earthworm activity provided more hiding space and shelter for collembola hence mediating pesticide effects on collembola and also resulting in less collembola caught in pitfall traps. The effects of earthworms on the abiotic and biotic properties of their environment [70] may also have deluded local impact of seed dressings, however this also reflects organismic interrelationships present in agroecosystems. Additionally, earthworm activity also reduced protozoan abundance in presence of seed dressings suggesting shifts in organismic interactions due to seed dressings. Earthworms and collembola also affected soil basal respiration suggesting that negative effects of seed dressing on decomposition rate might have been counterbalanced by microbial activity. Remarkably in the current study earthworms decreased wheat growth, which is in line with [71] and might be due to feeding activities on roots [35, 72]. Soil water content was significantly increased in the microcosms containing earthworms which is probably a result of the decreased plant growth due to earthworm activity $[22,23]$ and thus a decreased transpiration of the winter wheat plants leading to higher soil moisture. 


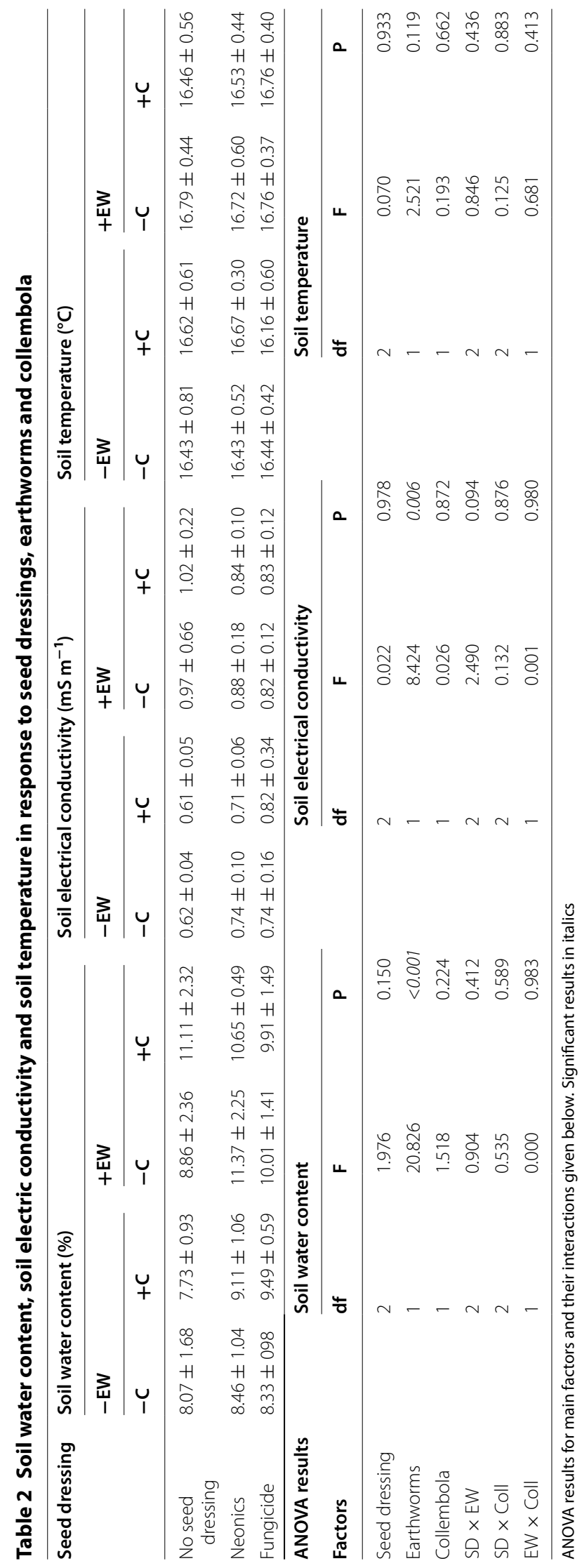



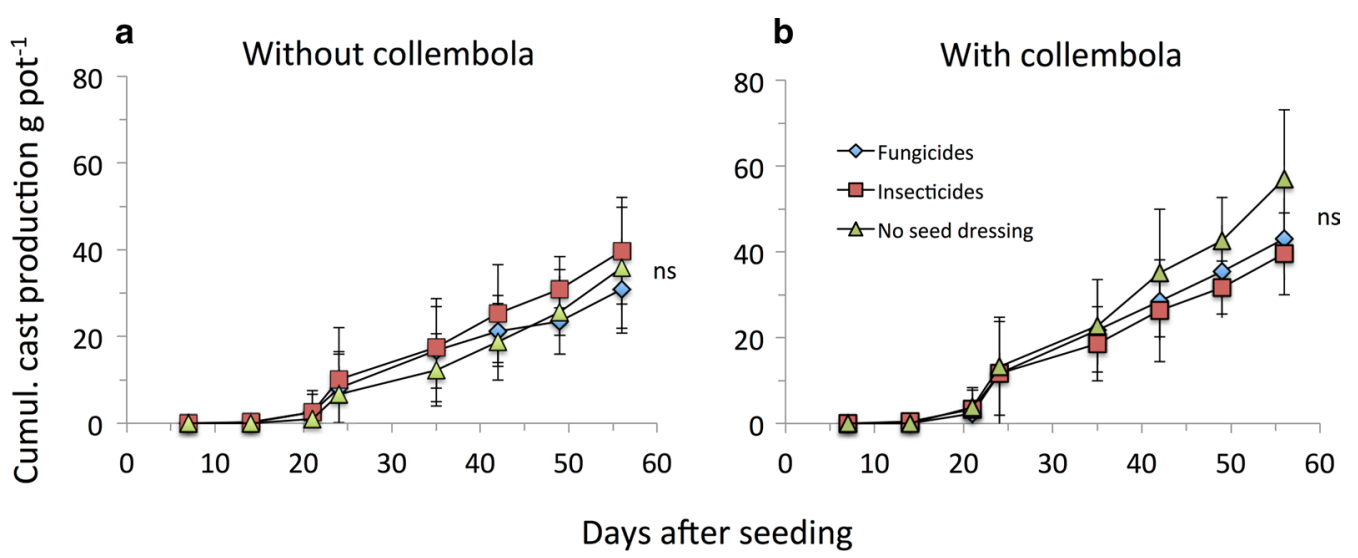

Fig. 3 Earthworm surface activity in response to pesticide seed dressings in microcosms without (a) and with collembola $(\mathbf{b})$. Mean $\pm S D, n=5 ; n s$ denote no significant difference between seed dressings
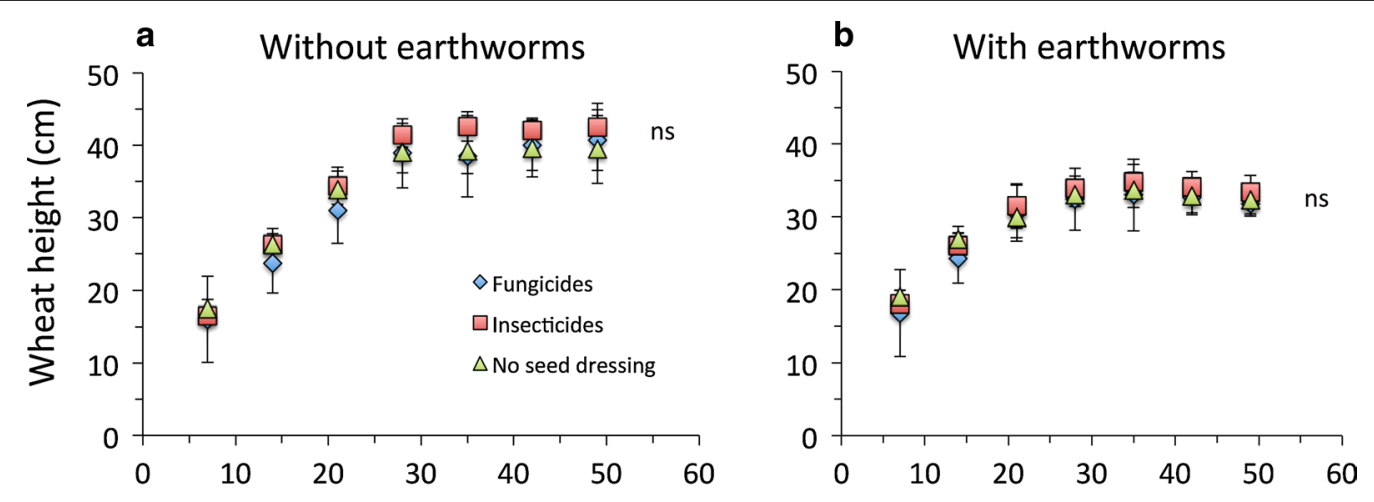

Days after seeding

Fig. 4 Wheat height growth in response to pesticide seed dressings in microcosms without (a) or with earthworms (b). Mean $\pm S D, n=5 ; n s$ denote no significant difference between seed dressings

\section{Conclusions}

Our findings suggest that pesticide seed dressing of wheat not only influence abundances and activities of soil micro- and mesofauna but might also alter nutrient cycling (via litter decomposition) with potential consequences for the functioning of agroecosystems. Soil macrofauna (earthworms) activity appeared to be less affected by seed dressings. This study is a first attempt to investigate potential non-target effects of seed dressings under more realistic circumstances including organismic interactions rather than only testing specific isolated active ingredients in laboratory settings. The tested effects of seed dressings on soil biota indicate that complex interspecific interactions such as resource- and interference competition may influence the assessment of non-target effects of pesticides. The reported effects may seem subtle, however it has to be noted that they were observed after a one-time application of only 18 seeds per experimental unit. However, under real farming conditions pesticide dressed seeds are sown on the same field at least twice a year with accumulating pesticide levels in soils [2] and potentially more pronounced non-target effects and feed backs on the composition of soil biotic communities and agroecosystem functioning [73]. Clearly, long-term field investigations are needed to further clarify potential effects of agrochemicals used for seed dressings on non-target soil organisms.

\section{Authors' contributions}

NK, AT, JGZ, YM, PQ, RK and AR contributed to data collection and/or data analysis. JGZ, NK, AT, RK, PQ, AR and MB wrote the majority of the paper with contributions from the co-authors. All authors read and approved the final manuscript.

\section{Author details}

${ }^{1}$ Institute of Zoology, University of Natural Resources and Life Sciences Vienna (BOKU), Vienna, Austria. ${ }^{2}$ Institute for Seed and Propagating Material, Phytosanitary Service and Apiculture, Austrian Agency for Health and Food Safety (AGES), Vienna, Austria. ${ }^{3}$ Department of Terrestrial Ecology, Institute 
of Zoology, University of Cologne, Cologne, Germany. ${ }^{4}$ Forschungszentrum Jülich, Institute of Bio- and Geosciences, IBG-2: Plant Sciences, Jülich, Germany.

\section{Acknowledgements}

We are grateful to Karl Refenner and Pia Euteneuer from the BOKU Research Farm Groß-Enzersdorf for providing the soil substrate. Mailin GauppBerghausen and Judith Zehetgruber gave statistical advise.

\section{Competing interests}

The authors declare that they have no competing interests.

\section{Availability of data and material}

The dataset supporting the results of this article is available with open access in the digital repository Zenodo Research.Shared (zenodo.org): http://dx.doi. org/10.5281/zenodo.59008.

\section{Funding}

No funding was received for this research.

Received: 30 December 2015 Accepted: 3 August 2016 Published online: 17 August 2016

\section{References}

1. Taylor A, Eckenrode C, Straub R. Seed coating technologies and treatments for onion: challenges and progress. Hortscience. 2001;36:199-205.

2. Goulson D. An overview of the environmental risks posed by neonicotinoid insecticides. J Appl Ecol. 2013;50:977-87.

3. Goulson D. Neonicotinoids impact bumblebee colony fitness in the field; a reanalysis of the UK's Food and Environment Research Agency 2012 experiment. PeerJ. 2015;3:e854.

4. Pisa LW, Amaral-Rogers V, Belzunces LP, Bonmatin JM, Downs CA, Goulson D, Kreutzweiser DP, Krupke C, Liess M, McField M, et al. Effects of neonicotinoids and fipronil on non-target invertebrates. Environ Sci Poll Res. 2015;22:68-102.

5. Rundlöf M, Andersson GKS, Bommarco R, Fries I, Hederstrom V, Herbertsson L, Jonsson O, Klatt BK, Pedersen TR, Yourstone J, Smith HG. Seed coating with a neonicotinoid insecticide negatively affects wild bees. Nature. 2015;521:77-80.

6. Commission European. Commission Implementing Regulation (EU) No 485/2013 of 24 May 2013 amending Implementing Regulation (EU) No 540/2011, as regards the conditions of approval of the active substances clothianidin, thiamethoxam and imidacloprid, and prohibiting the use and sale of seeds treated with plant protection products containing those active substances. Off J Eur Union. 2013;139:12-26.

7. Godfray HCJ, Blacquière T, Field LM, Hails RS, Petrokofsky G, Potts SG, Raine NE, Vanbergen AJ, McLean AR. A restatement of the natural science evidence base concerning neonicotinoid insecticides and insect pollinators. Proc Roy Soc B. 2014;7:281.

8. Edwards CA, Bohlen PJ, Linden DR, Subler S. Earthworms in agroecosystems. In: Hendrix PF, editor. Earthworm ecology and biogeography in North America. Michigan: Lewis Publishers; 1995. p. 185-213.

9. Lee KE. Earthworms. Their ecology and relationships with soils and land use. Syndey: Academic Press; 1985.

10. Edwards CA, Hendrix P, Arancon NQ: Biology and Ecology of Earthworms. 4th edn; 2013.

11. Capowiez Y, Cadoux S, Couchand P, Roger-Estrade J, Richard G, Biozard $\mathrm{H}$. Experimental evidence for the role of earthworms in compacted soil regeneration based on field observations and results from a semi-field experiment. Soil Biol Biochem. 2009:41:711-7.

12. Zaller JG, Arnone JA. Activity of surface-casting earthworms in a calcareous grassland under elevated atmospheric $\mathrm{CO}_{2}$. Oecologia. 1997;111:249-54.

13. Sheehan C, Kirwan L, Connolly J, Bolger T. The effects of earthworm functional diversity on microbial biomass and the microbial community level physiological profile of soils. Europ J Soil Biol. 2008;44:65-70.

14. Wolters V. Biodiversity of soil animals and its function. Europ J Soil Biol. 2001;37:221-7.
15. Rusek J. Biodiversity of collembola and their functional role in the ecosystem. Biodiv Conserv. 1998;7:1207-19.

16. Trap J, Bonkowski M, Villenave C, Blanchart E. Ecological importance of soil bacterivores for ecosystem functions. Plant Soil. 2015;74:1-24.

17. Koller R, Robin C, Bonkowski M, Ruess L, Scheu S. Litter quality as driving factor for plant nutrition via grazing of protozoa on soil microorganisms. FEMS Microbiol Ecol. 2013;85:241-50.

18. Hunt H, Coleman DC, Ingham E, Ingham R, Elliott E, Moore JC, Rose S, Reid C, Morley C. The detrial food web in a shortgrass prairie. Biol Fertil Soils. 1987;3:57-68.

19. Crotty F, Adl S, Blackshaw R, Murray P. Protozoan pulses unveil their pivotal position within the soil food web. Microb Ecol. 2011;63:1-14.

20. Pelosi C, Barot S, Capowiez Y, Hedde M, Vandenbulcke F. Pesticides and earthworms. A review. Agron Sustain Dev. 2014;34:199-228.

21. Schnug L, Jensen J, Scott-Fordsmand JJ, Leinaas HP. Toxicity of three biocides to springtails and earthworms in a soil multi-species (SMS) test system. Soil Biol Biochem. 2014;74:115-26.

22. Zaller JG, Heigl F, Ruess L, Grabmaier A. Glyphosate herbicide affects belowground interactions between earthworms and symbiotic mycorrhizal fungi in a model ecosystem. Sci Rep. 2014;4:5634. doi:10.1038/ srep05634.

23. Gaupp-Berghausen M, Hofer M, Rewald B, Zaller JG. Glyphosate-based herbicides reduce the activity and reproduction of earthworms and lead to increased soil nutrient concentrations. Sci Rep. 2015;5:12886. doi:10.11038/srep12886.

24. Chagnon M, Kreutzweiser D, Mitchell EAD, Morrissey CA, Noome DA, Van der Sluijs JP. Risks of large-scale use of systemic insecticides to ecosystem functioning and services. Environ Sci Poll Res. 2015;22:119-34.

25. Capowiez Y, Bastardie F, Costagliola G. Sublethal effects of imidacloprid on the burrowing behaviour of two earthworm species: modifications of the 3D burrow systems in artificial cores and consequences on gas diffusion in soil. Soil Biol Biochem. 2006;38:285-93.

26. Capowiez Y, Rault M, Mazzia C, Belzunces L. Earthworm behaviour as a biomarker-a case study using imidacloprid. Pedobiologia. 2003:47:542-7.

27. Capowiez Y, Rault M, Costagliola G, Mazzia C. Lethal and sublethal effects of imidacloprid on two earthworm species (Aporrectodea nocturna and Allolobophora icterica). Biol Fertil Soils. 2005;41:135-43.

28. Capowiez Y, Dittbrenner N, Rault M, Triebskorn R, Hedde M, Mazzia C. Earthworm cast production as a new behavioural biomarker for toxicity testing. Environ Poll. 2010;158:388-93.

29. Drobne D, Blazic M, Van Gestel CAM, Leser V, Zidar P, Jemec A, Trebse P. Toxicity of imidacloprid to the terrestrial isopod Porcellio scaber (Isopoda, Crustacea). Chemosphere. 2008;71:1326-34.

30. Jacobsen CS, Hjelmsø MH. Agricultural soils, pesticides and microbial diversity. Curr Opin Biotechnol. 2014;27:15-20.

31. Peck DC. Comparative impacts of white grub (Coleoptera: Scarabaeidae) control products on the abundance of non-target soil-active arthropods in turfgrass. Pedobiologia. 2009;52:287-99.

32. Peck DC. Long-term effects of imidacloprid on the abundance of surface- and soil-active nontarget fauna in turf. Agric For Entomol. 2009;11:405-19.

33. Bandow C, Coors A, Karau N, Römbke J. Interactive effects of lambdacyhalothrin, soil moisture, and temperature on Folsomia candida and Sinella curviseta (Collembola). Environ Toxicol Chem. 2014;33:654-61.

34. Schnug L, Leinaas $H$, Jensen J. Synergistic sub-lethal effects of a biocide mixture on the springtail Folsomia fimetaria. Environ Poll. 2014;186:158-64

35. Curry JP, Schmidt O. The feeding ecology of earthworms-A review. Pedobiologia. 2007;50:463-77.

36. Jorgensen H, Johansson T, Canbäck B, Hedlund K, Tunlid A. Selective foraging of fungi by collembolans in soil. Biol Lett. 2005;1:243.

37. Bandow C, Karau N, Römbke J. Interactive effects of pyrimethanil, soil moisture and temperature on Folsomia candida and Sinella curviseta (Collembola). Appl Soil Ecol. 2014;81:22-9.

38. Eijsackers H, Beneke P, Maboeta M, Louw JPE, Reinecke AJ. The implications of copper fungicide usage in vineyards for earthworm activity and resulting sustainable soil quality. Ecotoxicol Environ Saf. 2005;62:99-111.

39. Chapman P. Integrating toxicology and ecology: putting the "eco" into ecotoxicology. Marine Poll Bull. 2002;44:7-15. 
40. Tschischej M. Mit Winterweizen zum Erfolg. Kärntner Bauer 2013:11-13.

41. Edwards CA, Bohlen PJ. Biology and ecology of earthworms. 3rd ed. London: Chapman \& Hall; 1996.

42. Querner P, Bruckner A. Combining pitfall traps and soil samples to collect Collembola for site scale biodiversity assessments. Appl Soil Ecol. 2010;45:293-7.

43. Keuskamp JA, Dingemans BJJ, Lehtinen T, Sarneel JM, Hefting MM. Tea Bag Index: a novel approach to collect uniform decomposition data across ecosystems. Methods Ecol Evol. 2013;4:1070-5.

44. Setälä H, Marshall VG, Trofymow JA. Influence of body size of soil fauna on litter decomposition and ${ }^{15} \mathrm{~N}$ uptake by poplar in a pot trial. Soil Biol Biochem. 1996;28:1661-75.

45. Prescott CE. Litter decomposition: what controls it and how can we alter it to sequester more carbon in forest soils? Biogeochemistry. 2010;101:133-49.

46. Anderson JM, Domsch KH. A physiological method for quantitative measurement of microbial biomass in soils. Soil Biol Biochem. 1978;10:215-21.

47. Scheu S. Automated measurement of the respiratory response of soil micro compartments: active microbial biomass in earthworm faeces. Soil Biol Biochem. 1992;24:1113-8.

48. Beck T, Joergensen RG, Kandeler E, Makeschin F, Nuss E, Oberholzer HR, Scheu S. An inter-laboratory comparison of ten different ways of measuring soil microbial biomass C. Soil Biol Biochem. 1997;29:1023-32.

49. Darbyshire JF, Wheatley R, Greaves M, Inkson R. A rapid micromethod for estimating bacterial and protozoan populations in soil. Rev Ecol Biol Sol. 1974;11:465-75.

50. Page F. An illustrated key to freshwater and soil amoebae. Ambleside: Freshwater Biological Association; 1976.

51. Hurley M, Roscoe M. Automated statistical analysis of microbial enumeration by dilution series. J Appl Bacteriol. 1983;55:159-64.

52. Coûteaux M-M, Bottner P, Berg B. Litter decomposition, climate and liter quality. Trends Ecol Evol. 1995;10:63-6.

53. Hättenschwiler S, Tiunov AV, Scheu S. Biodiversity and litter decomposition in terrestrial ecosystems. Ann Rev Ecol Evol Syst. 2005;36:191-218.

54. Fernández D, Voss K, Bundschuh M, Zubrod JP, Schäfer RB. Effects of fungicides on decomposer communities and litter decomposition in vineyard streams. Sci Total Environ. 2015;533:40-8.

55. Rønn R, McCaig AE, Griffiths BS, Prosser JJ. Impact of protozoan grazing on bacterial community structure in soil microcosms. Appl Environ Microbiol. 2002;68:6094-105.

56. Ekelund F. Enumeration and abundance of mycophagous protozoa in soil, with special emphasis on heterotrophic flagellates. Soil Biol Biochem. 1998;30:1343-7.

57. Ekelund F, Rønn R. Notes on protozoa in agriculture soil with emphasis on heterotrophic flagellates and naked amoebae and their ecology. FEMS Microbiol Rev. 1994;15:321-53.
58. Foissner W. Soil protozoa as bioindicators: pros and cons, methods, diversity, representative examples. Agric Ecosyst Environ. 1999;74:95-112.

59. Couteaux MM, Darbyshire JF. Functional diversity amongst soil protozoa. Appl Soil Ecol. 1998;10:229-37.

60. Bonkowski M. Protozoa and plant growth: the microbial loop in soil revisited. New Phytol. 2004;162:617-31.

61. Alphei J, Bonkowski M, Scheu S. Protozoa, Nematoda and Lumbricidae in the rhizosphere of Hordelymus europaeus (Poaceae): faunal interactions, response of microorganisms and effects on plant growth. Oecologia. 1996;106:111-26.

62. Bonkowski M, Geoghegan IE, Birch ANE, Griffiths BS. Effects of soil decomposer invertebrates (protozoa and earthworms) on an above-ground phytophagous insect (cereal aphid), mediated through changes in the host plant. Oikos. 2001;95:441-50.

63. El-Naggar J, Zidan N-H. Field evaluation of imidacloprid and thiamehoxam against sucking insects and their side effects on soil fauna. J Plant Protect Res. 2013;53:375-87.

64. Stotefeld L, Scheu S, Rohlfs M. Fungal chemical defence alters densitydependent foraging behaviour and success in a fungivorous soil arthropod. Ecol Entomol. 2012;37:323-9.

65. Alves PRL, Cardoso E, Martines AM, Sousa JP, Pasini A. Seed dressing pesticides on springtails in two ecotoxicological laboratory tests. Ecotoxicol Environ Saf. 2014;105:65-71

66. OECD. Test No. 232: Collembolan reproduction test in soil, OECD guidelines for the testing of chemicals, Section 2. OECD Publishing; 2009.

67. Zaller JG, Saxler N. Selective vertical seed transport by earthworms: implications for the diversity of grassland ecosystems. Eur J Soil Biol. 2007:43:586-91.

68. Eisenhauer N, Marhan S, Scheu S. Assessment of anecic behavior in selected earthworm species: effects on wheat seed burial, seedling establishment, wheat growth and litter incorporation. Appl Soil Ecol. 2008;38:79-82.

69. Regnier E, Harrison SK, Liu J, Schmoll JT, Edwards CA, Arancon N, Holloman C. Impact of an exotic earthworm on seed dispersal of an indigenous US weed. J Appl Ecol. 2008;45:1621-9.

70. Eisenhauer $\mathrm{N}$. The action of an animal ecosystem engineer: identification of the main mechanisms of earthworm impacts on soil microarthropods. Pedobiologia. 2010;53:343-53.

71. Zaller JG, Parth M, Szunyogh I, Semmelrock I, Sochurek S, Pinheiro M, Frank T, Drapela T. Herbivory of an invasive slug is affected by earthworms and the composition of plant communities. BMC Ecol. 2013;13:20.

72. Arnone JA, Zaller JG. Earthworm effects on native grassland root system dynamics under natural and increased rainfall. Front Plant Sci. 2014;5:152.

73. Frampton GK, Wratten SD. Effects of benzimidazole and triazole fungicide use on epigeic species of collembola in wheat. Ecotoxicol Environ Saf. 2000;46:64-72.

\section{Submit your next manuscript to BioMed Central and we will help you at every step:}

- We accept pre-submission inquiries

- Our selector tool helps you to find the most relevant journal

- We provide round the clock customer support

- Convenient online submission

- Thorough peer review

- Inclusion in PubMed and all major indexing services

- Maximum visibility for your research

Submit your manuscript at www.biomedcentral.com/submit
BioMed Central 